\title{
LEVIATÃ DE THOMAS HOBBES: DIREITO À RESISTÊNCIA E ESTADO DE TRANSIÇÃO
}

\section{Aluisio Pampolha Bevilaqua}

Sociólogo, bolsista do CNPq no Mestrado em Educação Brasileira da Universidade Federal do Ceará - UFC, Membro do Conselho Editorial do Jornal INVERTA e do Conselho Editorial da Revista Ciência \& Luta de Classes do Centro de Educação Popular e Pesquisas Econômicas e Sociais - CEPPES.

\section{RESUMO:}

presente artigo tem por objetivo oferecer um novo olhar sobre a obra clássica Leviatã ou Matéria, Forma e Poder de Um Estado Eclesiástico e Civil, de Thomas Hobbes. Sustenta a hipótese de que as noções de soberania e liberdade transcendem a ideia de uma forma autoritária de governo feudal ou capitalista. Com base na dialética marxista, sugere que a concepção metafísica hobbesiana de Jus Naturale e Lex Naturalis sobrepõe o direito a vida à soberania do Estado, assentada em leis positivas e, do silogismo intrínseco a mesma, o direito à resistência dos súditos, a soberania limitada do Estado, as características universais de Estado de transição e tendência histórica dos períodos de crises revolucionárias e mudanças no modo de produção e formas de sociedade humana.

PALAVRAS-CHAVES: Hobbes, Leviatã, Liberdade, Resistência, Estado, Transição

\section{ABSTRACT}

This article aims to offer a new perspective on the classic work, Leviathan, or Matter, Form and Power of One State Ecclesiastical and Civil, of Thomas Hobbes. Supports the hypothesis that the notions of sovereignty and freedom transcend the idea of an authoritarian government of feudal or capitalist. Based on the Marxist dialectic, suggests that the metaphysical conception Hobbesian Natural Jus and Lex Naturales, overrides the right to life to the sovereignty of the state, founded on positive laws, and the syllogism is intrinsic to it, the right of resistance of subjects, limited sovereignty of the state, the universal features of transition state and the historical tendency of the periods of revolutionary crisis and changes in production methods and forms of human society.

KEY WORDS: Hobbes, Leviathan, Freedom, Resistance, State, Transition. 


\section{INTRODUÇÃO}

A teoria política do Estado moderno na Europa, em que se insere a teoria do Estado de Thomas Hobbes, Leviatã ou Matéria, Forma e Poder de Um Estado Eclesiástico e Civil, (1651), tem seus fundamentos a partir do Renascimento, como se observa nos trabalhos do florentino Nicolau Maquiavel (1469 - 1527), sobre a unificação da Itália, que de modo geral e com certo atraso vivia o processo dos países ibéricos (Portugal e Espanha): a unificação em Estado absolutista sustentado na associação de interesses entre a nobreza feudal e a burguesia mercantil, dando curso à revolução náutica e, consequentemente, às grandes navegações ultramarina. (SKENNER, 1996). Diante deste cenário surgiram as primeiras teorias do Estado moderno e prosperaram nos séculos XVII e XVIII, através da teoria e da prática liberal, guerra civil e experiências parlamentares até a revolução industrial, na Inglaterra (MACPHERSON, 1979); na França, chega à máxima expressão política com a revolução burguesa e o movimento teórico conhecido como Iluminismo ou Enciclopedismo; e encerra seu ciclo com a revolução filosófica na Alemanha (MARX e ENGELS, 1973).

Embora a interpretação histórica deste período não seja um consenso entre os estudiosos do mesmo, como sugere o trabalho de Barboza ao apontar a contradição entre a interpretação de Marx e Engels e a de Anderson, na medida que o debate se situa no campo do marxismo, isto permite localizar o problema metodológico e nos posicionar frente ao mesmo, sem prejuízo para o objetivo deste trabalho (BARBOZA, 2000).

O problema que se segue ao metodológico é definir o conteúdo histórico essencial das formações econômicas e sociais na Europa, especialmente a Inglaterra, que é a base empírica da qual Hobbes e os demais pensadores da época desenvolvem seu sistema teórico. A dificuldade nesta parte é, a partir das teses sobre este período, de Marx e Engels, Anderson, Hill, Althusser, definir qual o modo de produção dominante, seu caráter de classe e as formas ideológicas que se expressam na superestrutura da sociedade.

O passo seguinte é debater as noções de liberdade e soberania na teoria de Hobbes, a partir das principais interpretações atuais: Macpherson, Dumont e Bobbio; identificar as dificuldades destas abordagens, confrontando-as com a teoria de Hobbes, tendo em vista a hipótese desta pesquisa sobre sua obra. Superado este obstáculo, passaremos as considerações sobre a obra de Hobbes, em torno das noções de liberdade e soberania e as relações que estas estabelecem com o caráter geral do Estado e as formas de Governo em sua teoria. Finaliza-se este artigo com uma breve consideração sobre a hipótese sustentada no mesmo.

Com base nesta linha problemática o presente artigo se estrutura em sete partes: a primeira introduz o tema e aponta a linha problemática; a segunda, debate o método e as interpretações históricas do período em questão; a terceira, debate os principais comentadores de Hobbes; a quarta, analisa a obra Leviatã; a quinta, expõe a conclusão da pesquisa; a sexta, as referências bibliográficas; e a sétima, os anexos (extratos de textos da obra de Hobbes que sustentam a hipótese teórica deste artigo).

O trabalho pode ser considerado a partir da tentativa de desfazer o mito sobre o Leviatã de Hobbes, que igualmente a obra de Maquiavel - como adverte Cassirer - é reduzida à escatologia do Estado autoritário, supressão das liberdades (CASSIRER, 1976), pela lógica racional da "servidão voluntária" (BOÊTIE, 1982); também supo- 
mos que as reflexões sugeridas pelo mesmo possam interessar aos pesquisadores do tema, porque ele indica que: não basta ser Estado de direito (contratual) para ser Estado democrático; não basta ser Estado democrático (divisão de poderes) para ser Estado de liberdade; não basta ser Estado de liberdade (participação popular) para ser Estado liberal; e finalmente não basta ser Estado liberal (sociedade de mercado) para ser Estado de igualdade (SANTOS, 1978). O olhar sobre a obra de Hobbes como na obra de Marx exige a mesmo epígrafe: Qui si convien lasciare ogni sosppetto; / Ogni vità convien che qui sia morta. ${ }^{1}$

\section{MÉTODO MARXISTA APLICADO À HISTÓRIA}

Barboza, em seu trabalho Tradição e Artifício, Iberismo e Barroco na Formação Americana, afirmou que "a centralização do poder político nas mãos das coroas europeias e ocidentais, natureza essencial do absolutismo, é tradicionalmente entendida como um passo decisivo para a constituição das estruturas do mundo moderno, de modo especial para a estrutura do Estado moderno. Perry Anderson mostra que esta interpretação da história foi em parte estimulada por Marx e Engels, ao definir 'o absolutismo como forma de equilíbrio entre a antiga nobreza feudal e a burguesia emergente' e que (...) ‘o fenômeno do Absolutismo é a última forma de domínio da nobreza em território europeu, ainda determinada pelos imperativos da propriedade fundiária da aristocracia"” (BARBOZA, 2000, p. 259).

O debate, em torno das características essenciais do Absolutismo, apresenta dupla dificuldade: a primeira, de ordem histórica, a definição da base empírica que explica as abstrações teóricas do Estado moderno; a segunda, de ordem metodológica, saber se o marxismo é adequado a este objetivo. Tal como se apresenta a questão, aparenta grande dificuldade; mas, ao examinar sua essência, se observa que Anderson: a) fundamenta sua tese a partir da análise de Marx, "sobre a renda fundiária", em $O$ Capital; b) diferencia as formulações de Marx e Engels; c) define o problema em sua interpretação, como "um erro vulgar por confundir o fim da servidão com o desaparecimento das relações feudais no campo"; d) localiza a dificuldade na prática teórica marxista de separar modelos abstratos dos factuais" na lógica de determinação da superestrutura pela infraestrutura da sociedade; e) afirma que sua análise tem por base "unir os dois modelos" (ANDERSON, 1984, p 18-19).

Anderson se apoia no trabalho de Hill e Althusser para concluir que:

"Althusser especificou corretamente o seu caráter (...). Mas as dimensões da transformação histórica acarretada pelo advento do Absolutismo não devem ser minimizadas. Pelo contrário, é essencial aprender toda a lógica e todo o peso desta importante mudança de estrutura do Estado aristocrático e da propriedade feudal, que produziu o (...) Absolutismo". (ANDERSON, 1984, 18-19).

Nestes novos termos, o problema sugerido por Anderson se reduz ao caráter de classe do Estado, mas não altera as características gerais e o significado histórico que Marx e Engels lhe atribui de Estado de Transição. Considerando ainda que Hill e Althusser também não contestam este significado e características, e o próprio Anderson, diferentemente do que sugere Barbosa, enfatiza não se minimizar o peso

1 'Deixe aqui tudo é suspeito; /Mate-se aqui toda vileza. (Dante, A Divina Comédia) 


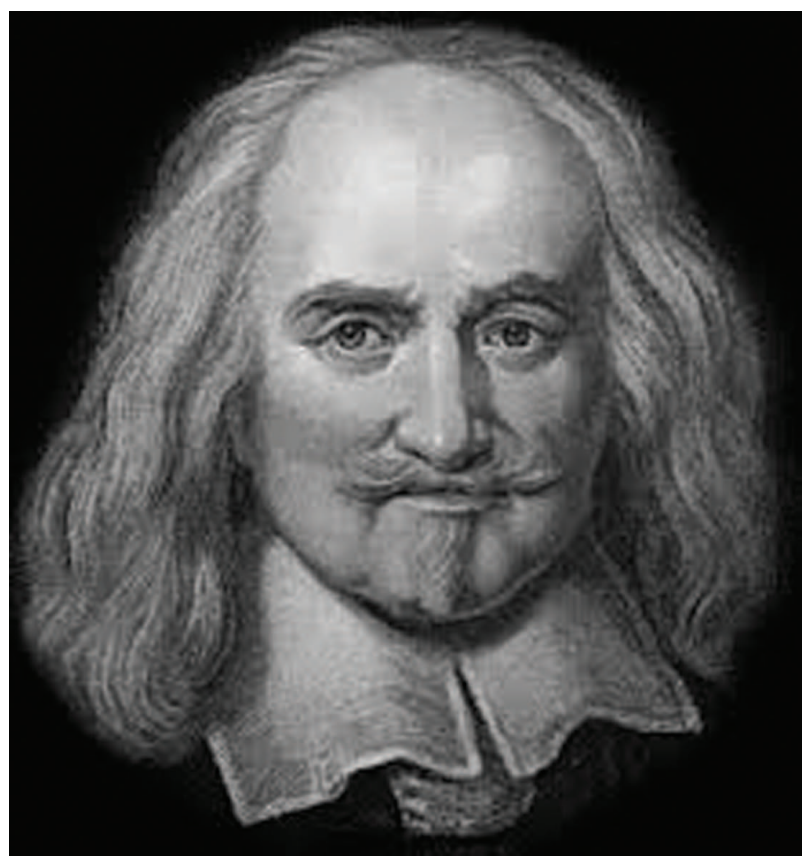

Thomas Hobbes (1588-1679)

e importância das transformações e mudança na estrutura do Estado aristocrático; então, conclui-se que a interpretação de Marx e Engels são críveis para efeito deste trabalho e, consequentemente, o método do materialismo dialético; além disso, que esta interpretação pode ser ampliada pelo trabalho de Anderson.

Contudo, o "erro vulgar" que Anderson atribui a Marx e Engels, de "confundir o fim da servidão com o desaparecimento das relações feudais no campo" e, segundo a lógica da determinação da superestrutura pela infraestrutura, o predomínio das relações capitalistas, logo, o caráter de classe do Estado de "equilíbrio" (Engels) ou "tipicamente burguês" (Marx), é, no mínimo, questionável. Primeiro, porque atribui à Marx e Engels uma interpretação mecânica da história, contrária ao seu próprio método. Segundo, porque toma a definição conjuntural de Estado de Engels como "tradicional", quando esta é do "Estado como resultado da luta e caráter inconciliável entre as classes" (Engels, 1984). Terceiro, porque confunde o significado histórico que Marx atribui ao Estado absolutista de "instrumento tipicamente burguês", com o caráter do mesmo questionando a base materialista na dialética das relações de determinação da superestrutura e infraestrutura na sociedade; quando sabe que este significado em Marx é resultado, justamente, de sua análise da Renda Fundiária no Livro III de $O$ Capital, com base em vasto material empírico e na dialética das metamorfoses históricas da categoria Renda (trabalho, produto e dinheiro), seja pelo desdobramento interno da categoria trabalho (excedente e necessário), seja pelas múltiplas relações com as categorias: propriedade, técnica, capital, dinheiro, classe, coerção e Estado; pois é nesta que Anderson se apoia.

Em todo caso, a tese de Anderson não altera a definição das características essenciais do Estado absolutista sustentadas por Marx e Engels, muito menos indica uma incoerência metodológica, como ele próprio reconhece ao cruzar perspectiva e resultado; mas, ao contrário, deixa tão somente transparecer suas próprias dificuldades com o método marxista, refletindo a velha polêmica althusseriana² e a deficiência teórica

2O filósofo Althusser defendeu a tese que a ruptura epistemológica de Marx com a filosofia hegeliana, implicava a necessidade de uma filosofia para marxismo, enunciada em A Ideologia Alemã, nas Teses sobre Feuerbach. 
de sua análise, comparando-a com a de Marx e Engels em O Capital. Contudo, é referência importante para este trabalho.

\section{OS COMENTADORES DE HOBBES}

"There is no royal road to learning, and the only people with any chance of scaling its sunlit peaks are those who have no fear of weariness when ascending the precipitous paths thatead up to them". ${ }^{3}$ (MARX, 1996, p. 23).

Esta epígrafe de Marx, inspirada em Euclides ${ }^{4}$, indica com precisão a dificuldade para quem postula encontrar um caminho para a Ciência, o que leva a imaginar também a dificuldade de interpretação seguindo a trajetória dos teóricos clássicos que fundamentam as Ciências Sociais e quanto maior a distância da base empírica que lhe deu significado, mais o quadro empírico e teórico atual impõe novos elementos ideológicos, conduzindo o olhar sobre estas teorias clássicas para novas interpretações. Este parece ser o caso da obra de Thomas Hobbes, Leviatã ou Matéria, Forma e Poder de Um Estado Eclesiástico e Civil, face às suas interpretações atuais, que examinaremos neste trabalho.

A interpretação de Macpherson parte da premissa que o indivíduo hobbesiano manifesta todas as tendências adquiridas na sociedade de soberania imperfeita, pois ao se retirar desta todas as leis e impedimentos, chega-se ao estado de guerra permanente de todos contra todos, tomado pelos desejos de lucro e glória e amor a nós mesmos. O raciocínio chave nesta interpretação é derivar da noção de amor próprio à noção de temor, pois nela repousaria toda a lógica pela qual este indivíduo racionalmente transfere seu direito natural de liberdade a todas as coisas ao Estado soberano.

Macpherson sustenta esta ideia argumentando o seguinte:

"Mas o medo não pode ser abstraído do Estado de Natureza e se 'mostra aumentado pela ausência do soberano'. Dai se conclui que o pleno estado de natureza ou estado de guerra contradiz a natureza (desejosa e medrosa) do homem. 'E assim ocorre que, através do medo que temos uns dos outros, achamos convenientes () e arranjamos alguns companheiros, estabelecendo ou reconhecendo um soberano capaz de nos proteger'. Portanto, as Paixões que inclinam os homens (naturais) à Paz, são o Medo e o Desejo (...) logo, o homem natural de Hobbes é o homem civilizado, apenas com a restrição legal removida”. (MACPHERSON, 1979: 40).

Ao se perguntar, que sociedade civilizada está na base do pensamento de Hobbes? A resposta de Macpherson é: “apenas uma espécie de sociedade, que chamo de sociedade de mercado possessivo, preenche realmente os requisitos da argumentação de Hobbes". E a partir disto teoriza que "a igualdade de todos em insegurança no estado natural, leva à igualdade de todos em submissão ao mercado no estado civilizado" e que o mecanismo para tal é o "cálculo racional dos proprietários (o custo-benefício) com a instituição de um soberano, com poderes de submeter todos ao desígnio do mercado”. Daí o pacto ou contrato entre os indivíduos proprietários de transferência

As teses de Althusser são consideradas estruturalistas por vários estudiosos do marxismo.

3 Não há estrada real para o conhecimento, e as únicas pessoas com alguma chance de escalar seus cismos luminosos são aqueles que não tem medo do cansaço de ascender os precipícios que conduzem até ele.

4 Euclides (c. 330 a. C. - 260 a. C.), sírio, viveu na Alexandria. Conta-se que, um dia, o rei lhe perguntou se não existia um método mais simples para aprender geometria e que Euclides respondeu: "Não existem estradas reais para se chegar à geometria". 
de seu poder para constituírem um poder soberano, ao qual todos devem obedecer e ficarem impedidos, moralmente, de contestar, o que implica dizer uma teoria do dever político de mercado (MACPHERSON, 1979: 59-60).

Macpherson explica que esta ideia não é uma ideia solta na cabeça de Hobbes, e indica que a divergência em torno do soberano em Locke e Harrington, não está no poder absoluto do soberano, mas na ideia de perpetuação de poder, ou seja, na tese de que todo o poder soberano tinha por direito natural o dever de se perpetuar indicando seu sucessor. Mas isto, em seu argumento, é devido à falta de clareza de Hobbes sobre o significado histórico e político das classes sociais e seu poder de articulação e unidade em torno da manutenção do poder, embora considere a burguesia uma ameaça real ao Rei. (MACPHERSON, 1979: 115).

Louis Dumont, em sua crítica à Macpherson, aceita com ressalvas a semelhança entre as teses "dos pobres artesãos niveladores e as teses do rico filósofo John Locke", cujo substrato é o individualismo possessivo; contudo, não pensa o mesmo da aplicação desta suposição teórica à interpretação de Hobbes, porque ela sustenta que Hobbes deduz sua noção de indivíduo no estado de natureza a partir da cena econômica, ao invés da cena política e da guerra civil, portanto é uma suposição pouco verossímil. (DOUMONT, 1985: 96-98).

Dumont interpreta a obra de Hobbes pela ótica do debate filosófico no "tomismo", entre os individualistas (societas), isto é, aqueles que veem o homem como um ser social, e os holistas (universitas), que veem o homem como parte de um organismo social. Concorda com Macpherson que o homem no estado de natureza de Hobbes é o homem no "estado social menos alguma coisa", isto é, menos a sujeição, entretanto, deixa em aberto este conteúdo social, concluindo então que é através da sujeição política que passamos "do homem para a comunidade" (Commonwealth - o corpo político ou o Estado). Ele relaciona ainda o pensamento de Hobbes, em torno da guerra de todos contra todos no estado de natureza, como prolongamento da ideia da guerra de interesses em Maquiavel; por outro lado, a ruptura do seu pensamento com a escolástica teológica baseada em Aristóteles, do homem como animal social. Neste aspecto, "o homem hobbesiano não é um ser inato, mas necessariamente social, uma ideia que será desenvolvida por Rousseau” (DUMONT, 1985, p. 99).

No que se refere ao problema da liberdade individual ao poder soberano, afirma:

“(...) Não há dúvida sobre o seu ponto de partida: é o ser humano particular, o individuo bumano. Mas, no estado pré-politico, a vida desse ser só pode ser julgada negativamente: "solitário, pobre, sujo, animalesco e curto" (mas como traduzir o inimitável "solitary, poor, nasty, brutish and shorfl). Quando, obedecendo ao conselho da razão e de seu próprio desejo de conservação, esse ser entra no estado politico, ele desfaz-se de uma parte de seus poderes. O homem é então capaz de alcançar a segurança, o conforto () mas ao preço da sujeição." (DUMONT, 1985: 99-100).

Apesar das discrepâncias com Macpherson, Dumont também estabelece a conexão entre o pensamento de Hobbes e as teses do utilitarismo de Jeremy Bentham (a parte mais conservadora do liberalismo), embora considere ambígua sua posição, entre o individualismo e o holismo; por um lado, o político, a ideia conservadora do Herrschaft (senhorio), em contraposição a Genossneschaft (sociedade cooperativa); e por 
outro lado, o sociológico, uma contribuição salutar, mesmo incompleta, de sociedade (DUMONT, 1985).

Norberto Bobbio, em comparação a Dumont, avança mais, ao analisar a teoria política de Hobbes, partindo da ideia que este rompe com as duas teses principais sobre a forma de governo na sua época: a tese sobre as formas boas e más de governo; e a tese do governo misto. Esta assertiva é sustentada nos atributos fundamentais da soberania: seu caráter absoluto e indivisibilidade. Do conceito de caráter absoluto da soberania do Estado advém a crítica à ideia das formas boas e más de governo; do conceito de indivisibilidade, a crítica ao governo misto (BOBBIO, 1997, p. 107).

Bobbio sustenta que "o conceito de poder soberano advém do seu caráter absoluto, porque se não fosse absoluto não seria soberano: soberania e caráter absoluto são unum et idem", e deste truísmo afirma que esta concepção em Hobbes é irredutível, seja em relação às leis positivas (leis constitucionais), seja em relação às leis naturais e divinas, ou do direito privado. Destaca as leis naturais e divinas que o soberano obedece, das leis positivas as quais não se subordina, mas também que a subordinação às primeiras é ao nível da consciência e não ao nível da aplicação de um poder comum, como dos súditos (BOBBIO, 1997, p. 108).

Em torno da questão da liberdade parte da ideia que, em Hobbes, esfera privada é igual a estado de natureza, portanto esta distinção entre a esfera pública e a privada é negada e com a instituição do Estado se dissolve inteiramente na esfera pública, isto é, nas relações de domínio que ligam o soberano aos súditos. Justifica este pensamento indagando: por que razão os indivíduos deixam o estado de natureza para ingressarem na esfera do Estado?

"é justamente porque o primeiro não é regulado por leis impostas por um poder comum, se resolvendo numa situação de conflito permanente (o famoso Bellum omnium contra omnes). Para Hobbes, o direito de propriedade só existe no Estado mediante a tutela estatal. No estado de natureza os individuos teriam um jus in omnia - um direito sobre todas as coisas -, o que quer dizer que não teriam direito a nada, já que todos tem direito a tudo" (BOBBIO, 1997, p. 108).

Quanto à perpetuação do poder, Bobbio aborda sobre a ótica do "princípio de efetividade", ou seja, da "legitimação post factum". Argumenta que a legitimidade do poder em Hobbes, em última instância, remonta um movimento contínuo de legitimação de um poder pelo outro até chegar forçosamente "ao ponto do poder que, como Atlas, não tem nenhum apoio além de si mesmo, no seu ato efetivo ou capacidade própria”. Em termos conceituais, pode-se dizer no máximo que o poder adquirido por conquista ou vitória pela guerra é um poder despótico - despotes - que significa senhor ou patrão. É o domínio que o patrão tem sobre o servo, como explica Hobbes (BOBBIO, 1997, p. 110).

Da noção de conservação da vida faz a analogia entre o pacto de constituição do Estado e o de legitimação do poder por conquista, como consequência lógica outorgada ao vencedor: "quando o vencido para evitar a morte - com palavras expressas ou sinais suficientes - indica que, enquanto lhe for concedido viver e ter liberdade de movimentos, o vencedor o utilizará à sua vontade". E desta noção "a tese que justifica o despotismo ex contractu, diferentemente da tese ex natura de Aristóteles e ex delicto de Bodin". Argumenta que ela não foge a lógica hobbesiana de passagem do indivíduo do estado de natureza ao estado civil, através da submissão a um poder 
comum, suficientemente forte para impedir o emprego da força particular, assegurando a vida dos indivíduos (BOBBIO, 1997, p. 111).

\section{SOBRE O DIREITO À RESISTÊNCIA EM HOBBES}

A leitura e interpretação da noção de soberania e liberdade na obra Leviatã, de Thomas Hobbes, exige, sem dúvida, grande complexidade, um exercício quase na tradição escolástica de hermenêutica e exegese. Contudo, o método adotado para compreender estas categorias no contexto do Leviatã, o marxismo, implica analisá-las pela ótica dialética das suas relações com o conteúdo histórico das contradições materiais, mediatizadas pelas formas ideológicas que às expressam na composição teórica de Hobbes para atingir o objetivo geral de seu trabalho. Isto implica dizer uma importância estrutural na relação interna com as demais categorias e com o objetivo geral e particular (interesse) do próprio autor.

As partes anteriores deste trabalho nos poupam de uma maior caracterização do cenário de interesses econômicos e políticos que sustentam as teorias de conformação dos Estados absolutistas, cujas teses desde Maquiavel rompiam com a concepção da polis e com o método escolástico. As ciências sociais, em especial, a ciência política, desde o Renascimento, se ancoraram nas ciências exatas para romper com este método. O movimento renascentista provoca a fissura à apodrecida hermenêutica eclesiástica, que no século XVII se expressa como ruptura através da teoria dos corpos de Galileu Galilei e recuperação da matemática euclidiana, do cálculo de máximo e mínimo denominador comum.

A ruptura econômica e social se desenvolve através do reflorescimento das economias europeias após a grande crise do século XIV, através do mercantilismo, mas também dos fisiocratas, primeiro movimento liberal; o método político de unificação dos Estados absolutos, com sua centralização e autoridade, sobre o manto da herança divina, repousava de fato na riqueza e alianças dos senhores feudais, para financiar exércitos, tanto para a conquista, quanto de defesa dos seus domínios territoriais, afogar as dissensões internas e proteger sua prosperidade econômica, industrial e comercial dos Estados unificados.

Os dois métodos de prosperidade econômica levam a ruptura religiosa até à Inglaterra, tornando-a o primeiro país a unir a ética protestante ao espírito capitalista, desencadeando a Reforma Religiosa e a disputa pelo domínio da Europa. A França, refúgio da nobreza papal, torna-se o centro da Contrarreforma; Portugal e Espanha a contraofensiva no domínio do além-mar, num pacto entre a nobreza, a Igreja e a burguesia mercantil (Armada, Companhia de Jesus, Companhia das Índias Ocidentais ou Orientais), que leva à revolução náutica e ao comércio mundial. Por via transversa, contribui com o desenvolvimento das ciências exatas.

$\mathrm{Na}$ Inglaterra, através do protestantismo, a ciência avança para o método experimental de Francis Bacon; e na França, refém da Igreja, surge o método racionalista de René de Descartes. O primeiro, influenciado pela teoria e método de Galileu, rompendo com o método escolástico e a metafísica aristotélica; o segundo, pela matemática de Euclides, rompe com a escolástica mantendo convivência com a metafísica aristotélica. É, justamente, na contradição entre estes dois métodos e na contradição destes com a escolástica, que se forma o sistema teórico e filosófico de 


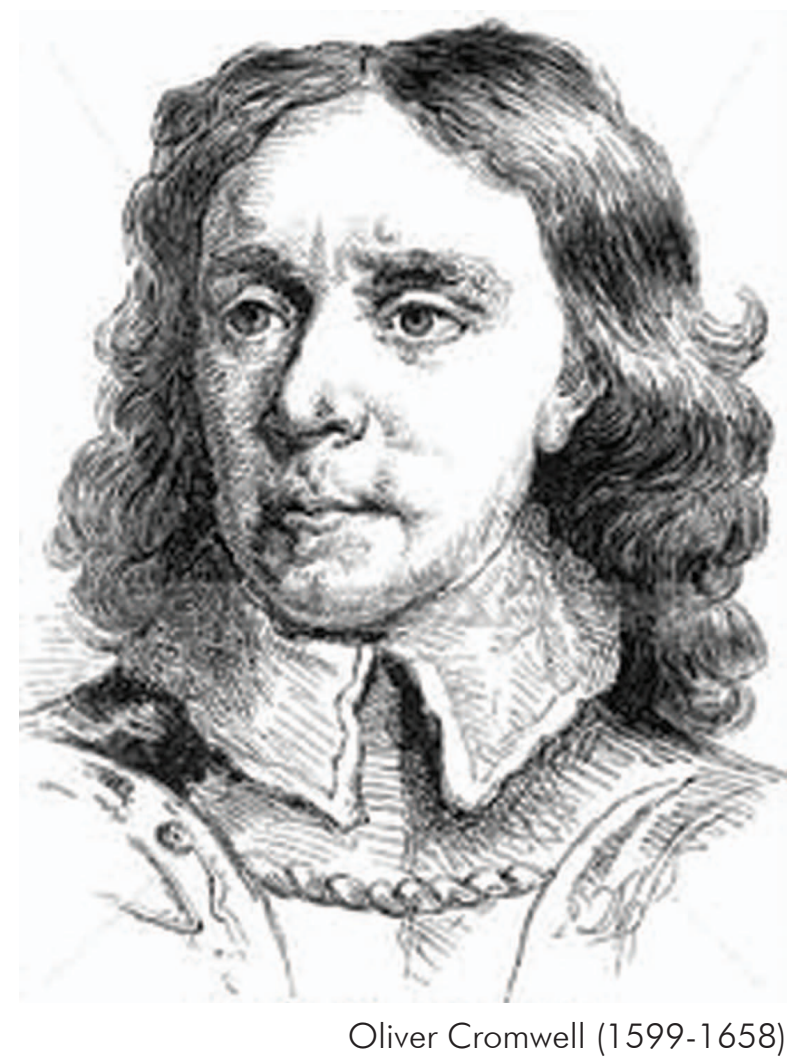

Thomas Hobbes; para Dela Volpe o método resolutivo-compositivo inspirado em Galileu (DELA VOLPE, 1972).

A luta histórica entre o parlamento e o rei na Inglaterra decorre desde 1215, quando o primeiro obriga o Rei João a assinar a Magna Carta, limitando o poder dos monarcas. Na tirania dos Stuarts, o poder volta às mãos do rei. Mas o reflorescimento da economia traz consigo o germe da destruição do modo de produção feudal: o capitalismo. E ao tempo de Hobbes já não vegetava, tornara-se o novo conteúdo histórico, liberal, da luta do parlamento contra o rei e o interesse de classe da revolução, que se expressa ora pelas correntes políticas, ora pelas correntes religiosas, ou ainda por correntes científicas, que condensam a luta liberal de ruptura com o sistema, no sentido econômico, político e ideológico.

O Leviatã veio a público em Londres, em 1651, período em que a revolução do Parlamento contra o Rei, iniciada em 1642, chega ao seu auge. Oliver Crommwell de 1649-1651, aprova a decapitação do rei Carlos I, constitui a República, adota a primeira constituição, é titulado Lorde Protetor. O governo constitui-se em Ditadura, esmaga as correntes divergentes, em especial os Escavadores, dissidência dos Niveladores, e com mão de ferro decreta medidas de proteção à economia inglesa e desenvolve a Marinha. Com sua morte, em 1658, seu filho, Richard Crommwell, o sucede, porém um ano depois abdica, o reinado é restaurado em 1660 e o Príncipe de Gales, a quem Hobbes fora preceptor até ser banido da corte por lançar o Leviatã em solo Inglês, assume o reino como Carlos II.

A teoria de Hobbes que surge neste período histórico não pode ser entendida fora deste contexto da transição do feudalismo ao capitalismo: a Inglaterra e Holanda viviam esta transição de forma mais avançada; França, Espanha e Portugal vivem

5 Líder da revolução pelos seus feitos militares, parlamentar e membro da corrente liberal dos puritanos. 
o processo de reação; Itália e Alemanha, o estacionário. Marx, em sua análise sobre o período pré-capitalista como nexo histórico entre o capital monetário e a renda da terra, no Livro III de $O$ Capital, explica sistematicamente este fato. Em termos da teoria de Hobbes, existe um nexo direto entre sua concepção do homem no estado de natureza sob o princípio da teoria dos corpos de Galileu, cuja igualdade de movimento livre e, por isso, conflitiva, reside na igualdade de desejos e paixões de sua propriedade corpórea, e na mimesis presente na mesma, como fator diferencial da natureza geral, que decorre do ato da gênese bíblica, como impulso inicial deste movimento. Assim, o homem hobbesiano é um corpo em movimento, vivo, em trânsito, logo em transição, cuja direção e sentido histórico depende, neste estado de natureza, da propriedade do seu corpo (força) e da utilização de um dos elementos especiais intrínseca a mesma, a mimesis (do órgão da razão) (HOBBES, 1983).

O homem natural hobbesiano, abstraído do processo social de transição, é um ser social cujas paixões e desejos oscilam entre o feudalismo e capitalismo, em termos subjetivos (lucro, riqueza, honra, liberdade e soberania, religião) e em termos objetivos, no domínio sobre os meios de conservação da vida (a propriedade privada, comunal e feudal). Esta concepção, embora mecânica, não chega a uma metafísica de tipo aristotélica, que se observa em Descartes ao aplicar a matemática euclidiana, como compreensão racional de uma dimensão subjetiva pelo qual se chega a Deus; mas, pela concepção materialista da teoria dos corpos, que pressupõe a razão como qualidade de mimesis, desenvolvida pelo homem em sua luta natural pela sobrevivência no estado de natureza, por conseguinte, uma qualidade material, cuja existência advém da gênese da natureza: "arte pela qual Deus fez e dirige o mundo"; logo, realidade a priori axiomática, o primeiro impulso a vida, ou seja, impulso ao movimento livre dos corpos e, portanto conflitivo, como definido anteriormente (HOBBES, 1983 p. 6 e 66).

Com base nesta concepção é possível explicar a natureza do processo conflitivo que vive a sociedade inglesa, a guerra civil, a guerra de todos contra todos; bem como se pode derivar uma dimensão antropológica e psicológica da natureza humana, propensa ao egoísmo, amoral, competitiva, prepotente e submissa, já que na lógica da matemática euclidiana o raciocínio é mera "soma e subtração", entre o bem maior e o mal menor regulado pela gravidade da conservação da vida. Além disso, se pode concluir que no sistema hobbesiano a noção de liberdade está ligada ao livre movimento que, se por um lado, explica "a ausência de impedimentos do homem sobre todas as coisas, inclusive os corpos dos outros"; por outro, implica a destruição da vida, na medida da guerra de todos contra todos pela conservação da vida; e ainda a noção de escolha entre o bem maior e o mal menor. Também é possível se compreender sua noção de soberania, que da propriedade natural sobre seu próprio corpo e dos meios de conservação da vida e ser social, avança até a soberania aos corpos dos demais homens e seus meios de subsistência e domínio territorial (HOBBES, 1983, p. 11 e 27).

Mas, neste caso liberdade e soberania são uma única e mesma coisa, e esta igualdade entre ambas, leva necessariamente à contradição e guerra permanente, adiantando em muito a teoria da evolução das espécies de Darwin. Contudo, é do exercício plenamente soberano da liberdade, como experiência sensorial do homem que se desenvolve os desejos e paixões, logo, impulsos intrínsecos que se exteriorizam em movimento do corpo, cuja mimesis, trabalha no aperfeiçoamento dos artefatos da 
experiência bem sucedida ou as refuta, evitando sempre o mal maior na conservação da vida, desenvolvendo a razão ou cálculo racional da efetivação dos objetos do desejo e paixões. Aqui o homem chega a compreensão racional que a conservação da vida é o bem maior, e que para tanto é necessário o mal menor, visto que liberdade e soberania em igualdade resultam no mal maior, que é a morte, e para que isto não aconteça é necessário dissociar de sua própria natureza de igualdade entre soberania e liberdade, como no resultado de um duelo em que por "sinais, palavras ou gestos claros" o derrotado escolhe o mal menor que é ceder parte da sua liberdade, o que quer dizer a soberania sob seu próprio corpo ao vencedor em troca da vida (HOBBES, 1983, p. 79-80).

É esta a explicação para a dissociação de liberdade e soberania no estado social, pensado como teleologia e cálculo racional dos homens tendo por princípio a conservação da vida diante do seu conflito permanente no estado de natureza. Contudo, é necessário diferenciar a ideia da formação do Estado da analogia com a constituição da soberania pela conquista, pois nesta última trata-se da efetivação ou legitimação do poder ex delicto, enquanto na verdade o primeiro é ex contractu, resultado da mediação da razão em evento teleológico a partir da projeção do conhecimento da realidade empírica para além da aparência no estado de transição, no estado de natureza do movimento livre dos homens, cuja premissa é conservação da vida, isto é, o bem maior pelo mal menor (HOBBES, 1983, p. 222).

Desta concepção, também se extrai um ideia positiva do homem hobbesiano, do homem que é a arte excelente de Deus, e por esta qualidade artífice capaz de imitar Deus copiando-se como estado projetado para seus objetivos comuns, com soberania superior a todos os homens, com seu movimento mais forte e livre, pois sua propriedade corpórea é a reunião dos corpos de todos os homens, colocando sob sua órbita de domínio ou soberania, ou poder, o movimento dos homens individuais em trajetória não conflitivas e utilizando-se para tal todos os instrumentos decorrentes desta soberania como vontade única a ser atingida como finalidade coletiva (HOBBES, 1983, p. 66).

Eis aqui a explicação da supressão de parte das liberdades individuais no estado social, que explica a soberania absoluta, como artifício humano que imita a si mesmo. Portanto, um Estado criado pelo estatuto da razão em que liberdade e soberania dissociadas se confrontam, em relações de determinação e condicionamento, e aquilo que era condição da liberdade no estado de natureza transforma-se em determinação desta, ao passo que aquilo que era determinação da soberania transforma-se em condição da mesma. Um pacto entre os homens que decorre da privação de parte do seu direito natural (HOBBES, 1983).

Desta concepção se extrai ainda o duplo estatuto que governa este Estado Social, derivado do estado de natureza, portanto a base racional do contrato dos homens entre si e de cada um com a totalidade destes, ou seja, o conjunto de "leis naturais" e o direito e leis positivas ou civis derivadas. As primeiras normatizam e regulam os direitos e deveres da soberania do Estado; as segundas normatizam os direitos e deveres dos homens para com o Estado e destes entre si. Aqui trata-se da noção geral do processo da formação do Estado, enquanto pacto de todos os cidadãos em torno dos objetivos pelo qual, cada um abre mão de parte de sua liberdade e soberania individual em nome da liberdade e soberania do Leviatã: "o objetivo da conservação da vida" (HOBBES, 1983, p. 78-85). 
Assim, ao contrário do que se pode imaginar da soberania artificial e da liberdade artificial do Estado absoluto em Hobbes, não é de forma alguma total este absoluto, na verdade, é bastante relativo e limitado, sujeito a mudanças e transformações para se manter em movimento rumo ao objetivo para o qual foi projetado e artificialmente criado e dotado de soberania, liberdade e poder sobre todos os homens. Um estado de transição que visa transpor a órbita do conflito do estado de natureza para órbita do estado social de "paz e prosperidade", como sugere "a primeira lei da natureza" e que depende para isto do seu órgão da razão, que é o governo para comandar o seu movimento dentro do cálculo racional do mal menor para o bem maior, contudo, com o preceito claro que é em caso de tal objetivo não ser atingido, os homens têm o direito de usar todos os meios disponíveis, inclusive os meios da guerra para conservação de si mesmos (HOBBES, 1983, p. 27 e 79).

Desta forma, o Leviatã hobbesiano é o Estado projetado para o processo de transição do feudalismo ao capitalismo, um Estado armado e equipado para conduzir os homens do estado de guerra permanente entre si ao estado de paz e prosperidade e de garantia da vida, e neste caso, pouco importa quem o comanda, se o Rei ou Parlamento, ou seja, se este governo é apenas um homem ou numa assembleia de homens. O que conta mesmo é sua indivisibilidade, unidade de vontade e poder de impulsionar, ou mesmo coagir a todos ao objetivo comum pactuado como finalidade do mesmo. Portanto com base nos documentos anexos, extratos dos capítulos I a XXIV do Leviatã, é que sustentamos as seguinte hipóteses:

a) A noção do "Direito de Resistência" em Hobbes está presente como problema teórico na sua formulação do Estado soberano (Artificial), como qualidade sensível e tendência psíquica em sua concepção da natureza do homem; e, finalmente, na própria lógica do seu método científico; b) da concepção do homem análoga à teoria dos corpos de Galileu, que na sua concepção de estado social é de um estado de transição, cuja liberdade de movimento é estabelecida artificialmente pelos fins que decorrem do pacto realizado pelos homens, em torno do objetivo comuns da paz e prosperidade como garantia da vida; c) que as características de Estado forte, com poder centralizado e soberania decorrentes da unidade de vontade e poder repressivo, para coagir todos os homens aos seus objetivos comuns e impedir as dissensões internas, não podem ser reduzidas à forma de governo autoritário de uma classe social no exercício do seu domínio de classe ou soberania sobre a sociedade civil, mas uma forma de Estado específica, tendência histórica nos processos de transição, crises revolucionárias e transformações nas formas da sociedade humana; e d) que todas estas afirmações sugerem a hipótese da importância da releitura de Hobbes e o reconhecimento de sua obra, Leviatã, como teoria que transcende o processo histórico específico e nos auxilia na compreensão dos processos atuais por que passam os países que vivem a crise de transição do capitalismo ao socialismo, bem como a reação diante da mesma, dos EUA e Europa, ou situações estacionárias de países na África, Ásia e América Latina.

\section{CONCLUSÃO}

Como demonstra este trabalho, ao responder certas interrogações teóricas adotadas como pontos de apoio à noção do "Direito de Resistência", na teoria do Estado em Hobbes, trata-se de uma hipótese plausível e passível de um trabalho de maior 
fôlego e relevância para a teoria política do Estado moderno. Também, como se pode observar, desde o primeiro capítulo deste trabalho, este olhar sobre a obra de Hobbes indica a ideia que sua teoria do Estado registra algo mais do que a configuração de Estado moderno, pois sugere a noção de Estado de transição que nos remetem às noções e categorias sociais que permitem compreender melhor os processos políticos vividos pelos Estados em outras épocas históricas, como o Estado romano, durante a passagem do escravismo ao feudalismo e, atualmente, os Estados socialistas, onde se processa a transição da sociedade do capitalismo para o comunismo.

Talvez seja um tanto audacioso ao estabelecer este problema para a teoria de Hobbes, e talvez, quem sabe, exigir demais do seu pensamento político. Contudo, não se pode deixar de observar que certo número de pensadores e formuladores da ciência política estão sempre às voltas com dificuldades na análise das teorias sobre o Estado moderno, ao se tomar o exemplo Macpherson, em seu trabalho sobre os fundamentos da teoria liberal para encontrar uma base sólida para solucionar sua crise; o mesmo é válido para os que se encontram no campo das teorias socialistas, cujo desaparecimento da URSS e de vários países se impôs como problema. Não se quer dizer com isto que na obra de Hobbes se encontre as respostas aos problemas cruciais para os tempos modernos, mas apenas estabelecer a noção que dadas características presentes em sua teoria, a centralização de poderes, a tendência à homogeneização e a necessidade de um esforço social ao estilo do esforço de guerra, parecem cada vez mais evidentes nestes momentos especiais.

Também não é possível reduzir da teoria do Estado de Hobbes a configuração de uma forma de governo que, na tradição da literatura política, se descreve como ditatorial ou totalitário, como apresenta Bobbio. Naturalmente, não se está afirmando que na teoria do Estado de Hobbes não existam traços que permitam esta formulação; pois da mesma forma que ele construiu seu modelo de estado de natureza deduzido do estado social existente e do primeiro estabeleceu sua teoria sobre um Estado artificial, perfeito, sobre a forma de governo ditatorial, também se pode somar ou deduzir elementos para montar um modelo ou forma de governo ou Estado de nosso arbítrio. Entretanto, uma questão deve ser dita: nos parece uma atitude teórica pouco aceitável vergar sua teoria até ao nível de contrapeso da teoria da forma de governo democrática, ou da teoria do Estado liberal-democrático.

Neste esforço, transparece mais o signo da discriminação dos pensadores fora dos cânones teológicos de ontem; e fora dos cânones liberais democráticos de hoje. Mas, apesar destas incongruências da ciência, sua obra resiste, e a cada dia que a sociedade marcha para a desfiguração dos Estados nacionais e o modelo político oficial da sociedade capitalista, configurando-se em Estado imperial, suas características tendem para as características do Estado hobbesiano. Um claro exemplo deste processo podemos observar pelas características centrais dos Estados que buscaram a hegemonia mundial durante o século XX, vejam o Estado nazista ou fascista, vejam os Estados socialistas, e atualmente, os Estados Unidos.

Não há dúvida que certas configurações que permeiam a teoria do Estado hobbesiano estão presentes na atual cena histórica, como demonstra o esforço dos teóricos liberais ou democráticos de realçar apenas seu vínculo teórico com a teoria liberal e o utilitarismo de Bentham, em oposição a uma configuração mais democrática e salvadora do modelo capitalista de Estado, visíveis na valorização das teses do social liberalismo a partir de John Stuart Mill. 


\section{BIBLIOGRAFIA}

ALTHUSSER, Louis. Montesquieu, la politique et Vhistoire. 5 edição, Paris: Pesses Universitaires,1981.

A favor de Marx - Pour Marx. Rio de Janeiro: Zahar Editora, 1979.

ANDERSON, Perry. Linhagens do Estado Absolutista. Porto: Edições Afrontamento, 1984.

ARON, Raymond. Etapas do pensamento sociológico. São Paulo: Martins Fontes, 1982.

BACHELARD, G. O novo espírito científico. Rio de Janeiro: Tempo Brasileiro, 1968.

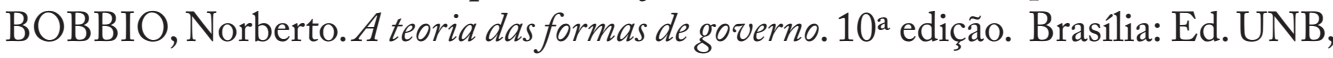
1997.

BOÊTIE, Etienne. Discurso da servidão voluntária. São Paulo: Ed. Brasiliense, 1982.

BRAVO, Carlos Ramiro. El pensamiento de Jeremy Benthan. Revista de Ciências Humanas, Colômbia, No.20, 2000.

CASSIRER, Ernest. O Mito do Estado. Rio de Janeiro: Zahar Editora, 1976.

CHEVALLIER, Jean-Jacques. História do Pensamento Politico. Rio de Janeiro, Zahar Editores, 1982.

DUMONT, Louis. O Individualismo - uma perspectiva antropológica da ideologia moderna. Rio de Janeiro, Ed. Rocco, 1985.

ENGELS, Friedrich. Origem da Familia, da Propriedade Privada e do Estado. Rio de Janeiro: Civilização Brasileira, 1984.

BARBOSA FILHO, Rubem. Tradição e Artifício - Iberismo e Barroco na formação americana. Belo Horizonte. Ed. UFMG, 2000.

GRAMSCI, Antonio. Maquiavel, a politica do Estado moderno. $7^{a}$ Edição. Rio de Janeiro: Civilização Brasileira, 1989.

HOBBES, Thomas. Leviatã ou matéria, forma e poder de um Estado eclesiástico e civil. São Paulo: Ed. Abril Cultural, 1983.

LANCASTER, Lane W. Master of Political Thought. Hegel to Derwey. London: George G. Harrap \& Co. Ltd., 1969.

LENIN, V. I. Cabiers sur la dialectique de Hegel. Paris, Éditions Gallimard, 1967. Cuadernos sobre el imperialismo. Obras Completas. Tomo 28. Moscú, Editorial Progreso, 1986.

LOCKE, John. Segundo Tratado sobre o Governo. São Paulo, Abril Cultural, 1978.

MACPHERSON, C. B. A teoria política do individualismo possessivo. Rio de Janeiro: Paz e Terra, 1979. 1973.

A democracia liberal - origens e evolução. Rio de Janeiro: Zahar Editora,

MAQUIAVEL, Nicolau. O Príncipe - Escritos Politicos. São Paulo: Ed. Abril Cultural, 1983.

MARCUSE, Herbert. Ideias sobre uma teoria crítica da sociedade. Rio de Janeiro: Zahar Editora, 1972.

MARX, Karl e ENGELS, Friedrich. La Ideologia Alemana. Buenos Aires: Ediciones Pueblos

Unidos, 1973. hart, 1996.

The Capital. Collected Works. Volume 35, London: Lawrence \&Wis-

MILL, Stuart. Princípio de Economia Política. São Paulo: Nova Cultural, 1986. 
2003.

Sobre a Liberdade. Edição eletrônica, Instituto Liberal do Rio de Janeiro,

POCOCK, J.G.A. The Machiavellian Moment. Florentine Political Thought and the Atlantic

Republican Tradition. Princenton: Princenton University Press.

SANTOS, Wanderley Guilherme dos. Ordem burguesa e liberalismo politico. São Paulo: Duas Cidades, 1978.

SERPA, Gustavo. Apuntes sobre la filosofia de Felix Varella. Habana: Editorial de Ciências Sociales, 1983.

SKINNER, Quentin. As fundações do pensamento politico moderno. São Paulo: Companhia das Letras, 1996.

TOCQUEVILLE, Aléxis. O antigo regime e a revolução. Brasília, Ed. UNB, 1979.

TOUCHARD, Jean. História das idéias políticas. Lisboa: Publicações Europa-América, 1970.

DELLA VOLPE, Galvano. Rousseau y Marx. Roma: Ediciones Martinez Roca S. A., 1972.

\section{ANEXOS:}

a) "Do mesmo modo que tantas outras coisas, a natureza (a arte mediante a qual Deus fez e governa o mundo) é imitada pela arte dos homens também nisso: que lhe é possível fazer um animal artificial. Pois vendo que a vida não é mais do que um movimento dos membros, cujo início ocorre em alguma parte principal interna, por que não poderíamos dizer que todos os autômatos (máquinas que se movem a si mesmas por meio de molas, tal como um relógio) possuem uma vida artificial? Pois o que é o coração, senão uma mola; e os nervos, senão outras tantas cordas; as juntas, senão outras tantas rodas, imprimindo movimento ao corpo inteiro, tal como foi projetado pelo Artífice? E a arte vai mais longe ainda, imitando aquela criatura racional, a mais excelente obra da natureza, o Homem. Porque pela arte é criado aquele grande Leviatã a que se chama Estado, ou Cidade (em latim Civitas), que não é senão um homem artificial, embora de maior estatura e força do que o homem natural, para cuja proteção e defesa foi projetado. E no qual a soberania é uma alma artificial, dá vida e movimento ao corpo inteiro..." (HOBBES, 1983, p. 5-6)

b) "Nenhum homem duvida da verdade da seguinte afirmação: quando uma coisa está imóvel, permanecerá imóvel para sempre, a menos que algo a agite. Mas não é tão fácil aceitar esta outra, que quando uma coisa está em movimento, permanecerá eternamente em movimento, a menos que algo a pare, muito embora a razão seja a mesma, a saber, que nada pode mudar por si só. ( ) Daí se segue que as escolas afirmam que os corpos pesados caem para baixo por falta de um desejo para repouso, e para conservação da sua natureza naquele lugar que é mais adequado para eles, atribuindo, de maneira absurda, a coisas inanimadas o desejo e o conhecimento do que é bom para sua conservação (o que é mais do que o homem possui).

Quando um corpo está em movimento, move-se eternamente (a menos que algo o impeça), e seja o que for que o faça, não o pode extinguir totalmente num só instante, mas apenas como o tempo e gradualmente, como vemos que acontece com a água, pois, muito embora o vento deixe de soprar, as ondas continuam a rolar durante muito tempo ainda. $\mathbb{Z}$ (HOBBES, 1983, p. 11). 
c) "O direito de natureza, a que os autores geralmente chamam jus naturale, é a liberdade que cada homem possui de usar seu próprio poder, da maneira que quiser, para a preservação de sua própria natureza, ou seja, de sua vida; e consequentemente de fazer tudo aquilo que seu próprio julgamento e razão lhe indiquem como meios adequados a esse fim".

"Uma lei de natureza (lex naturalis) é um preceito ou regra geral, estabelecido pela razão, mediante o qual se proíbe a um homem fazer tudo o que possa destruir sua vida ou privá-lo dos meios necessários para preservá-la, ou omitir aquilo que pense poder contribuir melhor para preservá-la. Porque, embora os que têm tratado deste assunto costumem confundir jus e lex, o direito e a lei, é necessário distingui-los um do outro. Pois o direito consiste na liberdade de fazer ou de omitir, ao passo que a lei determina ou obriga a uma dessas duas coisas. De modo que a lei e o direito se distinguem tanto como a obrigação e a liberdade, as quais são incompatíveis quando se referem à mesma matéria” (HOBBES, 1983, p. 78).

"E dado que a condição do homem (conforme foi declarado no capítulo anterior) é uma condição de guerra de todos contra todos, sendo neste caso cada um governado por sua própria razão, e não havendo nada de que possa lançar mão, que não possa servir-lhe de ajuda para a preservação de sua vida contra seus inimigos, segue-se daqui que numa tal condição, todo homem tem direito a todas as coisas, incluindo os corpos dos outros. Portanto, enquanto perdurar este direito de cada homem a todas as coisas, não poderá haver para nenhum homem (por mais forte e sábio que seja) a segurança de viver todo o tempo que geralmente a natureza permite aos homens viver. Consequentemente é um preceito ou regra geral da razão, que todo homem deve esforçar-se pela paz, na medida em que tenha esperança de consegui-la, e caso não a consiga pode procurar e usar todas as ajudas e vantagens da guerra. A primeira parte desta regra encerra a lei primeira e fundamental de natureza, isto é, procurar a paz, e segui-la. A segunda encerra a suma do direito de natureza, isto é, por todos os meios que pudermos,defendermo-nos a nós mesmos” (p. 78).

d) "Quando alguém transfere seu direito, ou a ele renuncia, fá-lo em consideração a outro direito que reciprocamente lhe foi transferido, ou a qualquer outro bem que daí espera. Pois é um ato voluntário, e o objetivo de todos os atos voluntários dos homens é algum bem para si mesmos. Portanto, há alguns direitos que é impossível admitir que algum homem, por quaisquer palavras ou outros sinais, possa abandonar ou transferir. Em primeiro lugar, ninguém pode renunciar ao direito de resistir a quem o ataque pela força para tirar-lhe a vida, dado que é impossível admitir que através disso vise a algum benefício próprio. $\mathrm{O}$ mesmo pode dizer-se dos ferimentos, das cadeias e do cárcere, tanto porque desta aceitação não pode resultar benefício, ao contrário da aceitação de que o outro seja ferido ou encarcerado, quanto porque é impossível saber, quando alguém lança mão da violência, se com ela pretende ou não provocar a morte. Por último, o motivo e fim devido ao qual se introduz esta renúncia e transferência do direito não é mais que a segurança da pessoa de cada um, quanto à sua vida e quanto aos meios de preservá-la de maneira tal que cabe por dela se cansar. Portanto, se através das palavras ou outros sinais um homem parecer despojar-se do fim para que esses sinais foram criados, não deve entender-se que é isso que ele quer dizer, ou que é essa a sua vontade, mas que ele ignorava a maneira como estas palavras e ações irão ser interpretadas”. (HOBBES, 1983: 80).

e) "Um pacto em que eu me comprometa a não me defender da força pela força é sempre nulo. Porque (conforme acima mostrei) ninguém pode transferir ou renunciar ao seu direito de evitar a morte, os ferimentos ou o cárcere (o que é o único fim da renúncia ao direito), portanto a promessa de não resistir à força não transfere qualquer direito em pacto algum, nem é obrigatória. Porque embora se possa fazer um pacto nos seguintes termos: se eu não 
fizer isto ou aquilo, mata-me; não se pode fazê-lo nestes termos: se eu não fizer isto ou aquilo não te resistirei quando vieres matar-me. Porque o homem escolhe por natureza o mal menor que é o perigo de morte ao resistir, e não o mal maior, que é a morte certa e imediata senão resistir. E isto é reconhecido como verdadeiro por todos os homens, na medida em que conduzem os criminosos para a execução e para a prisão rodeados de guardas armados, apesar de esses criminosos terem aceitado a lei que os condena".

f) "Um pacto num sentido de alguém se acusar a si mesmo, sem garantia de perdão, é igualmente inválido. Pois na condição de natureza, em que todo homem é juiz, não há lugar para acusação, e no estado civil a acusação é seguida pelo castigo; sendo este força, ninguém é obrigado a não lhe resistir. $\mathrm{O}$ mesmo é igualmente verdadeiro da acusação daqueles por causa de cuja condenação se fica na miséria, como a de um pai, esposa ou benfeitor. Porque o testemunho de um tal acusador, senão for prestado voluntariamente, deve considerar-se corrompido pela natureza, e portanto não deve ser aceito; e quando o testemunho de um homem não vai receber crédito ele não é obrigado a prestá-lo. Também as acusações arrancadas pela tortura não devem ser aceitas como testemunhos. Porque a tortura é para ser usada como meio de conjetura, de esclarecimento num exame posterior e de busca da verdade; e o que nesse caso é confessado contribui para aliviar quem é torturado, não para informar os torturadores. Portanto não deve ser aceito como testemunho suficiente porque, quer o torturado se liberte graças uma verdadeira ou uma falsa acusação, fá-lo pelo direito de preservar a sua vida". (HOBBES, 1983: 84).

g) "A única maneira de instituir um tal poder comum, capaz de defendê-los das invasões dos estrangeiros e das injúrias uns dos outros, garantindo-lhes assim uma segurança... é conferir toda sua força e poder a um homem, ou a uma assembleia de homens, que possa reduzir suas diversas vontades, por pluralidade de votos, a uma só vontade. O que equivale a dizer: designar um homem ou uma assembleia de homens como representante de suas pessoas, considerando-se e reconhecendo-se cada um como autor de todos os atos que aquele que representa sua pessoa praticar ou levar a praticar, em tudo o que disser respeito à paz e segurança comuns; todos submetendo assim suas vontades à vontade do representante, e suas decisões a sua decisão. Isto é mais do que consentimento, ou concórdia, é uma verdadeira unidade de todos eles, numa só e mesma pessoa, realizada por um pacto de cada homem com todos os homens, de um modo que é como se cada homem dissesse a cada homem: cedo e transfiro meu direito de governar-me a mim mesmo a este homem, ou a esta Assembleia de homens, com a condição de transferires a ele teu direito, autorizando de maneira semelhante todas as suas ações. Feito isso, à multidão assim unida numa só pessoa se chama Estado, em latim civitas. É esta geração daquele grande Leviatã, ou antes (para falar em termos mais reverentes) daquele Deus Mortal, ao qual devemos, abaixo do Deus Imortal, nossa paz e defesa. Pois graças a esta autoridade que lhe é dada por cada indivíduo no Estado, é-lhe conferido o uso de tamanho poder e força que o terror assim inspirado o torna capaz de conformar as vontades de todos eles, no sentido da paz em seu próprio país, e da ajuda mútua contra os inimigos estrangeiros. É nele que consiste a essência do Estado, a qual pode assim ser definida: Uma pessoa de cujos atos uma grande multidão, mediante pactos recíprocos uns com os outros, foi instituída por cada um como autora, de modo a ela poder usar a força e os recursos de todos, da maneira que considerar conveniente, para assegurar a paz e a defesa comum. Aquele que é portador dessa pessoa se chama soberano, e dele se diz que possui poder soberano. Todos os restantes são súditos.” (HOBBES, 1983: 105-106)

h) "Visto que o fim dessa instituição é a paz e a defesa de todos, e visto que quem tem direito a um fim tem direito aos meios, constitui direito de qualquer homem ou assembleia 
que tenha a soberania o de ser juiz tanto dos meios para a paz e a defesa quanto de tudo o que possa perturbar ou dificultar estas últimas. E o de fazer tudo o que considere necessário ser feito, tanto antecipadamente, para a preservação da paz e da segurança, mediante a prevenção da discórdia no interior e da hostilidade vinda do exterior, quanto também, depois de perdidas a paz e a segurança, para a recuperação de ambas. E, em consequência (...)

Em sexto lugar, compete à soberania ser juiz de quais as opiniões e doutrinas que são contrárias à paz, e quais as que lhe são propícias. E, em consequência, de em que ocasiões, até que ponto e o que se deve conceder àqueles que falam a multidões de pessoas, e de quem, deve examinar as doutrinas de todos os livros antes de serem publicados. Pois as ações dos homens derivam de suas opiniões, e é no bom governo das opiniões que consiste o bom governo das ações dos homens, tendo em vista a paz e a concórdia entre eles. E, embora em matéria de doutrina não se deva olhar a nada senão à verdade, nada se opõe à regulação da mesma em função da paz. Pois uma doutrina contrária à paz não pode ser verdadeira, tal como a paz e a concórdia não podem ser contrárias à lei da natureza”. (HOBBES, 1983: 110).

j) "Em sétimo lugar, pertence à soberania todo o poder de prescrever as regras através das quais todo homem pode saber quais os bens de que pode gozar, e quais as ações pode praticar, sem ser molestado por qualquer de seus concidadãos: é a isto que os homens chamam propriedade. Porque antes da constituição do poder soberano (conforme já foi mostrado) todos os homens tinham direito a todas as coisas, o que necessariamente provocava a guerra. Portanto esta propriedade, dado que é necessária à paz e depende do poder soberano, é um ato desse poder, tendo em vista a paz pública. Essas regras da propriedade (ou meum e tuum), tal como o bom e o mau, ou o legítimo e o ilegítimo nas ações dos súditos, são leis civis. Quer dizer, as leis de cada Estado em particular, embora hoje, o nome de direito civil se aplica apenas às antigas leis civis da cidade de Roma, pois sendo esta a capital de uma grande parte do mundo, suas leis eram nesse tempo o direito civil dessa região". (HOBBES, 1983: 110).

1) "É evidente que os homens que se encontrarem numa situação de absoluta liberdade poderão, se lhes aprouver, conferir a um só homem a autoridade de representar todos eles, ou então conferir essa autoridade a qualquer assembleia. Poderão, portanto, se tal considerarem conveniente, submeter-se a um monarca de maneira tão absoluta como a qualquer outro representante. Quando já estiver instituído um poder soberano, portanto, só será possível haver outro representante das mesmas pessoas para determinados fins particulares, definidos pelo próprio soberano. Caso contrário, instituir-se-iam dois soberanos, tendo cada um sua pessoa representada por dois atores, os quais se oporiam um ao outro, e assim necessariamente dividiriam esse poder que, para que o povo possa viver em paz, tem que ser indivisível. Assim, a multidão seria levada a uma situação de guerra, contrariamente ao fim para que é instituída toda a soberania" (HOBBES, 1983:114).

m) "Dado que a matéria de todas as formas de governo é mortal, de modo tal que não apenas os monarcas morrem, mas também assembleias inteiras, é necessário para a conservação da paz entre os homens que, do mesmo do modo que foram tomadas para a criação de um homem artificial, também sejam tomadas medidas para uma eternidade artificial da vida. Sem a qual os homens que são governados por uma assembleia voltarão à condição de guerra em cada geração, e com os que são governados por um só homem o mesmo acontecerá assim que morrer seu governante. Esta eternidade artificial é o que se chama direito de sucessão. (...) Não existe qualquer forma perfeita de governo em que a decisão da sucessão não se encontre nas mãos do próprio soberano. Porque se esse direito pertencer a qualquer outro homem, ou a qualquer assembleia particular, ele pertence a um súdito, e pode ser retomado pelo soberano a seu bel-prazer, e por consequência o direito pertence a ele próprio. 
Se o direito não pertencer a nenhuma pessoa em especial, e estiver na dependência de uma nova escolha, neste caso o Estado encontra-se dissolvido, e o direito pertence a quem dele puder apoderar-se, contrariamente à intenção dos que instituíram o Estado, tendo em vista uma segurança perpétua e não apenas temporária” (HOBBES, 1983: 119).

n) "De modo que aparece bem claro a meu entendimento, tanto a partir da razão quanto das escrituras, que o poder soberano, quer resida num homem, como numa monarquia, quer numa assembleia, como nos Estados populares e aristocráticos, é o maior que é possível imaginar que os homens possam criar. E, embora seja possível imaginar muitas más consequências de um poder tão ilimitado, apesar disso as consequências da falta dele, isto é, a guerra perpétua de todos os homens com seus vizinhos, são muito piores. Nesta vida a condição do homem jamais poderá deixar de ter alguns inconvenientes, mas num Estado jamais se verifica qualquer grande inconveniente a não ser os que derivam da desobediência dos súditos, e o rompimento daqueles pactos a que o Estado deve sua existência. E quem quer que considere demasiado grande o poder soberano procura fazer com que ele se torne menor, e para tal precisará submeter-se a um poder capaz de limitá-lo; quer dizer, a um poder maior" (HOBBES, 1983: 127).

o) "Passando agora concretamente à verdadeira liberdade dos súditos, ou seja, quais são as coisas que, embora ordenadas pelo soberano, não obstante eles podem sem injustiça recusar-se a fazer, é preciso examinar quais são os direitos que transferimos no momento em que criamos um Estado. Ou então, o que é a mesma coisa, qual a liberdade que a nós mesmos negamos, ao reconhecer todas as ações (sem exceção) do homem ou assembleia de quem fazemos nosso soberano. Porque de nosso ato de submissão fazem parte tanto nossa obrigação quanto nossa liberdade, (...).

Portanto, em primeiro lugar, dado que a soberania por instituição assenta num pacto entre cada um e todos os outros, e a soberania por aquisição em pactos entre o vencido e o vencedor, ou entre o filho e o pai, torna-se evidente que todo súdito tem liberdade em todas aquelas coisas cujo direito não pode ser transferido por um pacto. Já no capítulo 14 mostrei que os pactos no sentido de cada um abster-se de defender seu próprio corpo são nulos. Portanto, se o soberano ordenar a alguém (mesmo que justamente condenado) que se mate, se fira ou mutile a si mesmo, ou que não resista aos que o atacarem, ou que se abstenha de usar os alimentos, o ar, os medicamentos, ou qualquer outra coisa sem a qual não poderá viver, esse alguém tem a liberdade de desobedecer.

Se alguém for interrogado pelo soberano ou por sua autoridade, relativamente a um crime que cometeu, não é obrigado (a não ser que receba garantia de perdão) a confessá-lo, porque ninguém (conforme mostrei no mesmo capítulo) pode ser obrigado por um pacto a recusar-se a si próprio. Por outro lado, o consentimento de um súdito ao poder soberano está contido nas palavras eu autorizo, ou assumo como minhas todas as suas ações, nas quais não há qualquer espécie de restrição a sua antiga liberdade natural... Portanto, quando nossa recusa de obedecer prejudica o fim em vista do qual foi criada a soberania, não há liberdade de recusar; mas caso contrário há essa liberdade. Por esta razão, um soldado a quem se ordene combater o inimigo, embora seu soberano tenha suficiente direito de puni-lo com a morte em caso de recusa, pode não obstante em muitos casos recusar, sem injustiça, como quando se faz substituir por um soldado suficiente em seu lugar, caso este em que não está desertando do serviço do Estado. E deve também dar-se lugar ao temor natural, não só o das mulheres (das quais não se espera o cumprimento de tão perigoso dever), mas também o dos homens de coragem feminina. Quando dois exércitos combatem há sempre os que fogem (...) Não se considera que o fazem injustiça, é covardia (...). 
Ninguém tem a liberdade de resistir à espada do Estado, em defesa de outrem, seja culpado ou inocente... Mas caso um grande número de homens em conjunto tenha já resistido injustamente ao poder soberano, ou tenha cometido algum crime capital, pelo qual cada um deles pode esperar a morte, terão eles ou não a liberdade de se unirem e se ajudarem a defender uns aos outros? Certamente que a têm: porque se limitam a defender suas vidas, o que tanto o culpado como o inocente podem fazer (...)

Quanto às outras liberdades, dependem do silêncio da lei. Nos casos em que o soberano não tenha estabelecido uma regra, o súdito tem a liberdade de fazer ou de omitir, conforme a sua discrição (...)

Se um súdito tem uma controvérsia com seu soberano, quanto a uma dívida ou um direito de posse de terras ou bens, ou quanto a qualquer serviço exigido de suas mãos, ou quanto a qualquer penalidade, corporal ou pecuniária, baseando-se em qualquer lei anterior, tem a mesma liberdade de defender seu direito como se fosse contra outro súdito, e perante os juízes que o soberano exige por força uma lei anterior, e não em virtude de seu poder, declara por isso mesmo não estar exigindo mais do que segundo essa lei é devido (...).

Se um monarca ou uma assembleia soberana outorgarem uma liberdade a todos ou qualquer dos súditos, liberdade essa que lhe faz perder a capacidade de prover a sua segurança, a outorga é nula, a não ser que diretamente renuncie, ou transfira sua autoridade para outrem. (...)

Entende-se que a obrigação dos súditos para com o soberano dura enquanto, e apenas enquanto, dura também o poder mediante o qual ele é capaz de protegê-los. Porque o direito que por natureza os homens têm de defender-se a si mesmos não pode ser abandonado através de pacto algum. A soberania é a alma do Estado e uma vez separada do corpo os membros deixam de receber dela seu movimento. O fim da obediência é a proteção, e seja onde for que um homem a veja, quer em sua própria espada quer na do outro, a natureza manda que a ela obedeça e se esforce por conservá-la. Embora a soberania seja imortal, na intenção daqueles que a criaram, não apenas ela se encontra, por sua própria natureza, sujeita à morte violenta através da guerra exterior, mas encerra também em si mesma, devido à ignorância e às paixões dos homens, e a partir da própria instituição, grande número de sementes de mortalidade natural, através da discórdia intestina.

Se um súdito for feito prisioneiro de guerra, e ou sua pessoa ou seus meios de vida se encontrarem entregues à guarda do inimigo, e se sua vida e sua liberdade corpórea lhe forem oferecidas, com a condição de se tornar súdito do vencedor, ele tem a liberdade de aceitar essa condição... O caso será o mesmo se ele ficar retido nos mesmos termos, num país estrangeiro. Mas se um homem for mantido na prisão ou a ferros, ou se não lhe for confiada à liberdade sobre seu corpo, nesse caso não pode dizer-se que esteja obrigado a sujeição por um pacto, podendo portanto, se for capaz, fugir por quaisquer meios que sejam.

Se um monarca renunciar à soberania, tanto para si mesmo como para seus herdeiros, os súditos voltam à absoluta liberdade da natureza... Assim, se ele não tiver herdeiro não há mais soberania nem sujeição. O caso é o mesmo se ele morrer sem parentes conhecidos, e sem parentes conhecidos, e sem declarar quem deverá ser o herdeiro...”. (HOBBES, 1983: 133-136). 